LEADERSHIP, 2(2), Juni 2021, ISSN (online) : : 2715-0399

ISSN (Print out) : 2721-7108

Homepage : http://e-journal.staima-alhikam.ac.id/index.php/mpi

DOI : : 10.32478/leadership.v2i2. 714

Article type : Review Article

\title{
PEMBIAYAAN MAKRO PENDIDIKAN
}

\author{
Oleh: Fatahul Rahman \\ Sekolah Tinggi Ma'had Aly Al-Hikam Malang
}

\begin{abstract}
Education financing is an urgent matter in developing and implementing education. Macro education financing is financing that is carried out comprehensively in a country. This study aims to describe the nature of macro education financing and analyze the editorials of the National Education System Law and the Islamic Boarding School Law regarding education financing. This article is a type of qualitative research with a library research approach. The results of this study produce first, the essence of macro education financing is financing provided by the government, both central and local governments, all of which are budgeted for $20 \%$ of the total State Revenue and Expenditure Budget (APBN) and from the government itself the Regional Revenue and Expenditure Budget. Second, there are some differences in the analysis of the National Education System Law and the Islamic Boarding School Law in the financing of education, because in every exemption from Funding Sources, Fund Management and Salaries of Educators and Education Personnel there are different descriptions of the two laws.

Key words: Education Financing, Macro Financing, Law Analysis
\end{abstract}

\footnotetext{
Abstrak

Pembiayaan pendidikan adalah suatu hal yang urgen didalam merkembangan dan pelaksanaan pendidikan. Pembiayaan makro pendidikan adalah pembiayaan yang dilakukan secara komperhensip dalam suatu negara. Penelitian ini bertujuan untuk menguraikan hakekat pembiayaan makro pendidikan dan menganalisis redaksi-redaksi dari undang-undang Sisdiknas dan undang-undang pesantren mengenai pembiayaan pendidikan. Artikel ini termasuk jenis penelitian kualitatif dengan pendekatan

Email address: fatahulrahman61@gmail.com

LEADERSHIP: Jurnal Mahasiswa Manajemen Pendidikan is licensed under

The CC BY License (https://creativecommons.org/licenses/by-sa/4.0/)
} 
LEADERSHIP, 2(2), Juni 2021, ISSN (online) : :2715-0399

ISSN (Print out) : 2721-7108

Homepage : http://e-journal.staima-alhikam.ac.id/index.php/mpi

DOI : : 10.32478/leadership.v2i2. 714

Article type : Review Article

studi pustaka (library research). Hasil penelitian ini menghasilkan pertama, hakekat pembiayaan makro pendidikan adalah pembiayaan yang di berikan pemerintah, baik pemerintah pusat maupun pemerintah daerah yang semuanya dianggarkan $20 \%$ dari total Anggaran Pendapatan dan Belanja Negara (APBN) dan dari pemerintah sendiri Anggaran Pendapatan dan Belanja Daerah. Kedua, Analisis UU Sisdiknas dan UU Pesantren didalam pembiayaan pendidikan ada beberapa perbedaan, karena disetiap pemabasan baik dari Sumber Pendanaan, Pengelolaan Dana dan Gaji Pendidik dan Tenaga Kependidikan ada penjabaran-penjabaran yang berbeda dari kedua undang-undang tersebut.

Key word: Pembiayaan Pendidikan, Makro Pembiayaan, Analisis UU

\section{A. PENDAHULUAN}

Upaya pengembangan pendidikan disuatu negara merupakan suatu kewajaran dan keharusan. Dikatakan sebagai suatu kewajaran, karena kehadiran pendidikan yang berupa suatu produk budaya masyarakat dan bangsa, yang terus mengalami perkembangan untuk mencari karekteristik yang paling cocok, sesuai dengan perubahan dinamis yang terjadi saat ini dalam suatu masyarakat setiap bangsa. Dan demikianpula dikatakan sebagai suatu keharusan, karena pendidikan memiliki peran sangat penting didalam mengembangkan sumber daya manusia.

Pendidikan yang bermutu adalah aset bagi negara tersebut. Dalam melaksanakan pendidikan, negara harus memberikan dana atau menjadi sumber dana dari pendidikan tersebut, guna menjadikan pendidikan menjadi pendidikan yang bermutu. Pembiayaan pendidikan yang meliputi keseluruhan di suatu negara akan dibahas di Pembiayaan makro pendidikan. Sedangkan pembiayaan yang meliputi suatu lembaga atau istitusi saja maka akan dibahas di pembiayaan mikro pendidikan.

Pembiayaan makro pendidikan mencangkup keseluruhan wilayah atau suatu negara yang bersifat komplek, menyeluruh dan komperhensip. Pem-biayaan makro pendidikan diatur atau dibagi menjadi tiga tingkatan yakni pusat, D.I (provinsi) dan D.II (kabupaten). 
LEADERSHIP, 2(2), Juni 2021, ISSN (online) : :2715-0399

ISSN (Print out) : 2721-7108

Homepage : http://e-journal.staima-alhikam.ac.id/index.php/mpi

DOI : : 10.32478/leadership.v2i2. 714

Article type : Review Article

Adapun karya tulis ini, peneliti akan mejelaskan tentang hakekat pembiayaan makro pendidikan dan mencoba menganalisis dan membandingkan antara UU Sisdiknas dan UU pesantren.

\section{B. METODE PENELITIAN}

Artikel ini termasuk jenis penelitian kualitatif dengan pendekatan studi pustaka (library research). Dalam studi pustaka, penulis melakukan kegiatan pengumpulan literatur-literatur yang berkaitan dengan pembiayaan makro pendidikan, kemudian dilakukan penelaahan kembali terhadap literatur-literatur tersebut secara mendalam sehingga bisa menghasilkan kesimpulan yang valid dan dapat dipertanggungjawabkan

C. PEMBAHASAN

1. Hakekat Pembiayaan Makro Pendidikan

Pendidikan merupakan salah satu hal penting dalam membentuk sumber daya manusia yang berkualitas. Dalam UU Nomor 20 tahun 2003 Pasal 1 Ayat 1 menjelaskan bahwa:

Pendidikan adalah usaha sadar dan terencana untuk mewujudkan suasana belajar dan proses pembelajaran agar peserta didik secara aktif mengembangkan potensi dirinya untuk memiliki kekuatan spiritual keagamaan, pengendalian diri, kepribadian, kecerdasan, akhlak mulia, serta keterampilan yang diperlukan dirinya, masyarakat, bangsa dan negara. ${ }^{1}$

Pendidikan dibagi menjadi dua tingkat penyelenggaraan yakni mikro dan makro. Dalam hal penyelenggaraan pendidikan ditingkat makro (negara) yang termasuk penting adalah masalah pembiayaan, pembiayaan adalah suatu hal yang harus ada atau tersedia. Rida Firanika menyatakan dalam tulisannya:

Pemerintahan Republik Indonesia sesuai amanat Undang-undang setiap tahunnya telah mencanangankan alokasi anggaran pendidikan sebesar minima 20\% dari total Anggaran Pendapatan dan Belanja Negara (APBN), sama halnya dengan pemerintah daerah setiap tahunnya menetapkan anggaran untuk pendidikan seperti gaji guru dan gaji tenaga kerja Pendidikan lainnya di daerah. $^{2}$

\footnotetext{
${ }^{1}$ UU RI Nomor 20 tahun 2003. Hal.2
}

2 Rida Fironika K. Pembiayaan Pendidikan di Indonesia (Univ. Islam Sultan Agung: Jurnal Ilmiah Pendidikan Dasar) hal. 43-44. 
LEADERSHIP, 2(2), Juni 2021, ISSN (online) : :2715-0399

ISSN (Print out) : 2721-7108

Homepage : http://e-journal.staima-alhikam.ac.id/index.php/mpi

DOI $\quad: 10.32478 /$ leadership.v2i2. 714

Article type : Review Article

Jadi pembiyaan makro adalah pembiayaan yang bersipat menyeluruh, komplek, komperhenship dan umum.

Banyak hal yang mempengaruhi makro pendidikan yang dimana hal tersebut memiliki atau sangat penting kaitannya dengan pembiayaan pendidikan antara lain: Ekonomi, Ekosisitem, Sosial Budaya, Politik dan Keamanan.

a) Ekonomi

Ekonomi berpengaruh karena memang penting, karena Kesplo (perputaran uang) didalam suatu negaran itu menandakan kemandirian negara tersebut. Otomati dengan mandirinya negara tersebut dalam mengelola ekonomi, maka pembiayaan pendidikan di negara tersebut bisa diatasi atau terpenuhi. Sedangkan sebaliknya, tatkala di dalam suatu negara mengalami krisis ekonomi maka pembiayaan pendidikan juga mendapak efek dari hal tersebut (tidak terpenuhinya pembiayaan pendidikan).

b) Ekosistem (Lingkungan)

Lingkungan juga berpengaruh, karena tatkala terjadi bencana dan sebagainya dalam suatu daerah maka pembiayaan pendidikan juga bisa diperngaruhi oleh hal tersebut. Karena uang yang seharusnya dialokasikan kependidikan akan terpotong lagi dengan pembiayaan perbaikan atau pembelanjaan negara/daerah.

c) Sosial budaya

Sosial dan budaya yang terdapat dalam sutu negara atau daerah juga berpengaruh. Semisal suatu negara atau daerah tersebut memiliki budaya yang buruk seperti budaya korupsi, penyogokan, suap dan lain sebagainya. Maka pembiayaan pendidikanpun terkena dampak hal tersebut.

d) Politik

Disini pembiayaan berpengaruh dalam pendidikan dikarenakan kebijakan yang diputuskan oleh politikus/ pelaku politik.

e) Keamanan

Dan hal yang juga sangat berpengaruh dalam pembiayaan yakni keamanan negara. Rasa aman yang dimiliki suatu negara baik aman dari mara bahaya yang berasal dari luar negri maupun dalam negri. Karena tatkala keamanan suatu negara terancam, maka pengelolaan, pemberdayaan dan lain sebagainya terganggu dan tak terurus dann itu sangat berdampak bagi pembiayaan pendidikan. 
LEADERSHIP, 2(2), Juni 2021, ISSN (online) : :2715-0399

ISSN (Print out) : 2721-7108

Homepage : http://e-journal.staima-alhikam.ac.id/index.php/mpi

DOI : : 10.32478/leadership.v2i2. 714

Article type : Review Article

Poin-poin diatas bisa mempengaruhi didalam pembiayaan dan kelangsungan Pendidikan didalam suatu negara. Baik buruknya Pendidikan sutu negara juga bisa terpengaruhi oleh poin-poin tersebut.

Di dalam pembiayaan makro Pendidikan juga memiliki beberapa tingkatan yakni tingkat pusat atau yang sering kita ketahui dengan APBN (Anggaran Pendapatan dan Belanja Negara) yang dimana negara Indonsia memberikan amanat kepada pemerintah untuk menetapkan anggaran Pendidikan 20\% dari anggaran belanja negara seperti yang ada pada UUD 1945 yang telah amndemen Pasal 31 Ayat 4. Dan tingkat D.I (Provinsi) dan D. II (Kabupaten) keduanya masuk kedalam APBD (Anggaran Pendapatan dan Belanja Daerah).

2. Analisis UU Sisdiknas dan UU Pesantren

Fokus analisis yang saya lakukan adalah di bagian Sumber Pendanaan,

Pengelolaan Dana dan Gaji Pendidik dan Tenaga Kependidikan.

\section{SUMBER PENDANAAN}

Sumber pendanaan pendidikan dapat diartikan sebagai bentuk dana dimana pemenuhan kebutuhan dananya berasal dari negara. Didalam UU Sisdiknas dan UU Pesantren memiliki redaksi yang berbeda dalam merumuskan sumber pendanaan pendidikan ini. Adapun redaksi dari kedua UU tersebut sebaigai berikut:

\begin{tabular}{|c|c|}
\hline UU Sisdiknas & UU Pesantren \\
\hline $\begin{array}{l}\text { Pasal } 47 \\
\text { (1) Sumber pendidikan ditentukan } \\
\text { dengan prinsip keadilan, kecukupan, } \\
\text { dan ke-berlanjutan. }\end{array}$ & $\begin{array}{l}\text { Pasal } 48 \\
\text { (1) Sumber pendanaan penye- } \\
\text { lenggaraan Pesantren berasal } \\
\text { dari masyarakat. }\end{array}$ \\
\hline $\begin{array}{l}\text { (2) Pemerintah, Pemerintah Daerah, } \\
\text { dan masyarakat mengerahkan } \\
\text { sumber daya yang ada sesuai } \\
\text { dengan peraturan perundang- } \\
\text { undangan yang berlaku }\end{array}$ & $\begin{array}{l}\text { (2) Pemerintah Pusat membantu } \\
\text { pendanaan penyelengaraan } \\
\text { Pesantren melalui anggaran } \\
\text { pendapatan dan belanja } \\
\text { negara sesuai kemampuan }\end{array}$ \\
\hline $\begin{array}{l}\text { (3) Ketentuan mengenai sumber pen- } \\
\text { danaan pendidikan sebagaimana } \\
\text { dimaksud dalam ayat (1) dan ayat }\end{array}$ & $\begin{array}{l}\text { keuangan negara dan } \\
\text { ketentuan peraturan } \\
\text { perundang-undangan. }\end{array}$ \\
\hline
\end{tabular}


LEADERSHIP, 2(2), Juni 2021, ISSN (online) : :2715-0399

ISSN (Print out) : 2721-7108

Homepage : http://e-journal.staima-alhikam.ac.id/index.php/mpi

DOI : : 10.32478/leadership.v2i2. 714

Article type : Review Article

\begin{tabular}{|l|l|}
\hline $\begin{array}{l}\text { (2) diatur lebih lanjut dengan } \\
\text { Peraturan Pemerintah. }{ }^{3} .\end{array}$ & (3) Pemerintah Daerah membantu \\
pendanaan penyelenggaraan \\
Pesantren melalui anggaran \\
pendapatan dan belanja \\
daerah sesuai kewenangannya \\
dan ketentuan peraturan \\
perundang-undangan. \\
(4) Sumber pendanaan pe- \\
nyelenggaraan Pesantren \\
dapat berasal dari sumber lain \\
yang sah dan tidak mengikat \\
sesuai dengan ketentuan \\
peraturan perundang- \\
undangan. \\
(5) Sumber pendanaan Pesantren \\
yang berasal dari hibah luar \\
negeri diatur lebih lanjut dalam \\
Peraturan Presiden.
\end{tabular}

Dari kedua redaksi UU di atas, bisa kita simpulkan bahwa sumber pendanaan pesantren lebih banyak dari pada sumber pendanaan Sisdiknas dan juga Sumber pendanaan penyelenggaraan Pesantren dapat berasal dari sumber lain yang sah dan tidak mengikat.

\section{PENGELOLAAN DANA}

Pengelolaan dana adalah sutu hal yang sangat urgen. Didalam UU Sisdiknas dan UU Pesantren memiliki redaksi yang berbeda dalam pengelolaan dana pendidikan ini. Adapun redaksi dari kedua UU tersebut sebaigai berikut:

\begin{tabular}{|c|c|}
\hline \multicolumn{1}{|c|}{ UU Sisdiknas } & \multicolumn{1}{|c|}{ UU Pesantren } \\
\hline Pasal 48 & Pasal 49 \\
(1) Pengelolaan dana pendidikan ber- & (1) Pemerintah menyediakan dan \\
dasarkan pada prinsip keadilan, & $\begin{array}{l}\text { mengelola dana abadi } \\
\text { efisiensi, transparansi, dan akun- } \\
\text { tabilitas publik. }\end{array}$ \\
\hline
\end{tabular}

\footnotetext{
${ }^{3}$ UU20-2003 Sisdiknas.
}

${ }^{4}$ RUU Pesantren 2019. 
LEADERSHIP, 2(2), Juni 2021, ISSN (online) : :2715-0399

ISSN (Print out) : 2721-7108

Homepage : http://e-journal.staima-alhikam.ac.id/index.php/mpi

DOI : : 10.32478/leadership.v2i2. 714

Article type : Review Article

(2) Ketentuan mengenai pengelolaan dana pendidikan sebagaimana dimaksud dalam ayat (1) diatur lebih lanjut dengan Peraturan Pemerintah. $^{5}$ abadi pen-didikan.

(2) Ketentuan mengenai dana abadi Pesantren sebagaimana dimaksud pada ayat (1) diatur dengan Peraturan Presiden. ${ }^{6}$

Jadi, UU Sisdiknas lebih menekankan kepada prinsip dari Pengelolaan dana pendidikan. Sedangkan UU pesantren di Pasal 49 Ayat 1 menyatakan pemerintah menyediakan dan mengelola dana abadi pesantren.

\section{GAJI PENDIDIK dan TENAGA KEPENDIDIKAN}

Menurut Undang-Undang Republik Indonesia Nomor 20 Tahun 2003 tentang Pendidik dan Tenaga Pendidik:

Pendidik merupakan tenaga profesional yang bertugas merencanakan dan melaksanakan proses pembelajaran, menilai hasil pembelajaran, melakukan pembimbingan dan pelatihan, serta melakukan penelitian dan pengabdian kepada masyarakat, terutama bagi pendidik pada perguruan tinggi. ${ }^{7}$

Tenaga kependidikan bertugas melaksanakan administrasi, pengelolaan, pengembangan, pengawasan, dan pelayanan teknis untuk menunjang proses pendidikan pada satuan pendidikan. ${ }^{8}$

Perbandingan yang selanjutnya adalah gaji pendidik dan tenaga kependidikan.

\begin{tabular}{|l|l|}
\hline \multicolumn{1}{|c|}{ UU Sisdiknas } & UU Pesantren \\
\hline Pasal 40 & \\
(1) Pendidik dan tenaga kependidikan & \\
berhak memperoleh: \\
a. Penghasilan dan jaminan kesejah- \\
teraan sosial yang pantas dan \\
memadai;
\end{tabular}

${ }^{5}$ UU20-2003 Sisdiknas.

${ }^{6}$ RUU Pesantren 2019.

${ }^{7}$ UU20-2003 Sisdiknas. Pasal 39 Ayat 2

8 ... Pasal 39 Ayat 1 
LEADERSHIP, 2(2), Juni 2021, ISSN (online) : :2715-0399

ISSN (Print out) : 2721-7108

Homepage : http://e-journal.staima-alhikam.ac.id/index.php/mpi

DOI : : 10.32478/leadership.v2i2. 714

Article type : Review Article

\begin{tabular}{|l|l|}
\hline b. Penghargaan sesuai dengan tugas \\
dan prestasi kerja; \\
c. Pembinaan karier sesuai dengan \\
tuntutan pengembangan kualitas; \\
d. Perlindungan hukum dalam melak- \\
sanakan tugas dan hak atas hasil \\
kekayaan intelektual; dan \\
e. Kesempatan untuk menggunakan \\
sarana, prasarana, dan fasilitas. \\
pendidikan untuk menunjang \\
kelancaran pelaksanaan tugas.
\end{tabular}

Perbedaan yang sangat signifikan yang bisa kita temui didalam perbedaan undang-undang ini adalah dari UU pesantren tidak memiliki atau mengatur dan menetapkan gaji pengajar dan tengaga pengajar.

D. KESIMPULAN

Berdasarkan uraian diatas, maka dapat disimpulkan bahwa pertama, hakekat pembiayaan makro pendidikan adalah pembiayaan yang di berikan pemerintah, baik pemerintah pusat maupun pemerintah daerah yang semuanya dianggarkan $20 \%$ dari total Anggaran Pendapatan dan Belanja Negara (APBN) dan dari pemerintah sendiri Anggaran Pendapatan dan Belanja Daerah. Kedua, Analisis UU Sisdiknas dan UU Pesantren didalam pembiayaan pendidikan ada beberapa perbedaan, karena disetiap pemabasan baik dari Sumber Pendanaan, Pengelolaan Dana dan Gaji Pendidik dan Tenaga Kependidikan ada penjabaran-penjabaran yang berbeda dari kedua undang-undang tersebut.

\section{Daftar Rujukan}

K, Rida Fironika. Pembiayaan Pendidikan di Indonesia (Univ. Islam Sultan Agung: Jurnal IImiah Pendidikan Dasar)

RUU Pesantren 2019

Sukardi. Pengelolaan Sumber Dana Pendidikan Dasar. TESIS: Eprints 2010 UU no. 202003 Sisdiknas

\footnotetext{
${ }^{9}$ UU20-2003 Sisdiknas.
} 